\title{
Comparison of the radioisotope dilution-coated charcoal method and a microbiological method (L. leichmannii) for measuring vitamin $B_{12}$ in serum
}

\author{
J. L. RAVEN, P. L. WALKER, AND P. BARKHAN \\ From the Haematology Laboratory, Guy's Hospital, London
}

SYNOPSIS A comparison has been made of the radioisotope dilution-coated charcoal method and ${ }_{-}^{\circ}$ a microbiological assay (with $L$. leichmannii as test organism) for determining the concentration of $z$ vitamin $B_{12}$ in serum. A satisfactory correlation was found between the results of the two methods. Under appropriate conditions the reproducibility of the radioisotope method compared favourably with that of the microbiological method.

The absence of sensitive and reliable chemical methods for measuring the trace amounts of vitamin $B_{12}$ in serum led to the development of appropriate microbiological methods, which because of their great sensitivity and usefulness, have been used almost exclusively. Attempts to develop chemical methods have been made in the last few years, and radiochemical procedures based on isotope dilution assays have been described (Barakat and Ekins, 1961; Rothenberg, 1961) but these methods have not supplanted microbiological assays which continue to be widely used.

More recently, Lau, Gottlieb, Wasserman, and Herbert (1965) have described a relatively simple method of employing the principle of radioisotope dilution and the absorptive properties of coated charcoal. It appears to be as sensitive and reliable as microbiological assays for measuring vitamin $B_{12}$ and offers some technical advantages for routine use. Vitamin $B_{12}$ is admirably suited to this type of assay since it can be obtained in a radioactive form $\left({ }^{57} \mathrm{CoB}_{12}\right)$, it has a specific binder (intrinsic factor) which is easily available and the free but not the bound form can be removed by coated charcoal.

In this paper we report our experience with the method of Lau et al. (1965) in measuring the concentration of vitamin $B_{12}$ in serum and compare the results with those obtained by a standard microbiological procedure (L. leichmannii).

Received for publication 26 May 1966.

\section{METHODS}

OUTLINE AND PRINCIPLES OF THE RADIOISOTOPE METHOD Unlabelled vitamin $B_{12}$ is released from serum and dilutes the specific activity of a known quantity of added $\stackrel{2}{D}$ ${ }^{57} \mathrm{CoB}_{12}$. A representative sample of the mixture of unlabelled and radioactive $B_{12}$ is then bound to intrinsic $\bar{O}$ factor which, having a $B_{12}$-binding capacity less than the amount of added ${ }^{57} \mathrm{CoB}_{12}$, becomes saturated with the $\mathrm{B}_{12}$ mixture. Unbound $B_{12}$ is removed by absorption onto protein-coated charcoal. The degree of dilution of the radioactive $B_{12}$ is proportional to the amount of un-? labelled $B_{12}$ in the mixture and this will be reflected in $\frac{5}{3}$ the relative amounts bound to intrinsic factor. The concentration of $B_{12}$ in the serum can be calculated by com- $\delta$ paring the quantity of radioactive $B_{12}$ bound to intrinsic factor in the presence of the test serum with that in a을 control containing only intrinsic factor and an identical amount of ${ }^{57} \mathrm{CoB}_{12}$.

MICROBIOLOGICAL ASSAY Microbiological assay of serum $N$ vitamin $B_{12}$ level was carried out using Lactobacillus leichmannii as the test organism according to the method of Rosenthal and Sarett (1952). The organism (L. $\omega$ leichmannii, N.C.I.B. 8117) was obtained from the Torrey Research Station, Aberdeen, Scotland.

ISOTOPE DILUTION METHOD The isotope dilution method was carried out as described by Lau et al. (1965) with slight modifications.

1 PREPARATION OF TEST SERUM AND CONTROLS Into a $\frac{\rho}{\mathscr{}}$ $20 \mathrm{ml}$. screw-capped glass bottle (a Universal container) $\varrho$ were pipetted $3.0 \mathrm{ml}$. serum, $9.0 \mathrm{ml}$. saline, and $3.0 \mathrm{ml} . \bar{\gamma}$ 610 
$\mathrm{N} / 4$ hydrochloric acid. The mixture was shaken and then placed in a boiling water bath for 15 minutes (with the screw-cap in position to avoid volume loss by evaporation). After the bottle had cooled at room temperature, $3 \mathrm{ml} .{ }^{57} \mathrm{CoB}_{12}$ was added and the contents shaken. For serum supernatant controls, $3 \mathrm{ml}$. of the heated mixture was transferred to each of two $10 \mathrm{ml}$. polystyrene tubes, each containing $1.5 \mathrm{ml}$. saline (tubes 1 and 2). To the remaining mixture in the Universal container were then added $2 \mathrm{ml}$. working solution of intrinsic factor and $4 \mathrm{ml}$. of saline and the contents well mixed. From this mixture $4.5 \mathrm{ml}$. volumes were transferred to each of three $10 \mathrm{ml}$. polystyrene tubes (tubes 3,4 , and 5). To each of the five polystyrene tubes was added $2 \mathrm{ml}$. of coated charcoal suspension. These tubes were well mixed, centrifuged at 2,000 r.p.m. for 10 minutes and then $5 \mathrm{ml}$. of supernatant from each was transferred to counting tubes. (Volumes of exactly $5 \mathrm{ml}$. were required for the particular counting equipment.)

The intrinsic factor controls were prepared as follows: the initial mixture contained $12 \mathrm{ml}$. saline and $3 \mathrm{ml}$. $\mathrm{N} / 4 \mathrm{HCl}$. Since no serum was present, there was no need for heating, and $3 \mathrm{ml} .{ }^{57} \mathrm{CoB}_{12}$ was added immediately. For the intrinsic factor supernatant controls, $3 \mathrm{ml}$. of the mixture was transferred to each of two $10 \mathrm{ml}$. polystyrene tubes (tubes 6 and 7), each containing $1.5 \mathrm{ml}$. saline. To the remaining mixture were added $2 \mathrm{ml}$. working solution of intrinsic factor and $4 \mathrm{ml}$. saline; $4.5 \mathrm{ml}$. of this mixture was then transferred to each of three $10 \mathrm{ml}$. polystyrene tubes (tubes 8, 9, and 10). The subsequent treatment was identical to that for the sera.

2 COUNTING OF RADIOACTIVITY Each sample was counted for 100 seconds in a well-type scintillation counter.

3 CALCUlation OF SERUM VITAMIN B $_{12}$ CONCENTRATION was by means of the formula of Lau et al. (1965).

$$
\mathrm{pg} \mathrm{B}_{12} \text { per ml. serum }=C \times\left(\frac{I F}{S}-1\right)
$$

where $C=\mathrm{B}_{12}$ concentration in pg./ml. of ${ }^{57} \mathrm{CoB}_{12}$ standard

$$
\begin{aligned}
S & =\text { net counts per } 100 \text { seconds of test serum. } \\
& =\text { average of tubes } 3,4, \text { and } 5-\text { average of } \\
& \text { tubes } 1 \text { and } 2 . \\
I F & =\text { net counts per } 100 \text { seconds of intrinsic } \\
& \text { factor control } \\
& =\text { average of tubes } 8,9 \text {, and } 10 \text { - average of } \\
& \text { tubes } 6 \text { and } 7 .
\end{aligned}
$$

4 PREPARATION OF INTRINSIC FACTOR A hog intrinsic factor concentrate (batch no. 48743/131) supplied by Lederle Laboratories was used. (This preparation was also being used routinely for Schilling tests.) A stock solution of $100 \mathrm{mg} . / 100 \mathrm{ml}$. was prepared and after filtration through Whatman no. 1 filter paper its $\mathbf{B}_{12}-$ binding capacity was measured by the method of Gottlieb, Lau, Wasserman, and Herbert (1965). This stock solution was stable for at least six months at $-20^{\circ} \mathrm{C}$., but the working solution was prepared freshly for each batch of assays because it was found that the diluted solution lost
25 to $30 \%$ of its activity after a week at $4^{\circ} \mathrm{C}$. It was also found best for the assay to keep the $\mathbf{B}_{12}$-binding capacity of the working solution as close to $800 \mathrm{pg}$. $/ \mathrm{ml}$. as possible. The working solution was made by adding $1 \mathrm{ml}$. of the stock solution to $89 \mathrm{ml}$. of deionized water.

5 ALBUMIN - COATED CHARCOAL Activated charcoal powder (B.D.H.) and $30 \%$ bovine albumin (Armour) were used. Ten $\mathrm{g}$. of charcoal and $6.7 \mathrm{ml}$. of albumin were mixed and made up to $400 \mathrm{ml}$. with deionized water. This was stored at $4^{\circ} \mathrm{C}$. and remained active for at least a month. This was sufficient for the assay of $\mathbf{4 0}$ sera but was also used for intrinsic factor antibody tests and in practice a new batch was prepared every fortnight. The suspension was well shaken before use.

$6{ }^{57} \mathrm{CO}$ VITAMIN $\mathrm{B}_{12}\left({ }^{57} \mathrm{COB}_{12}\right) \quad$ Two batches, one $11 \mu \mathrm{c}$. $\mu \mathrm{g}$. and the other $15 \mu \mathrm{c}$./ $\mu \mathrm{g}$., were used. These were obtained from the Radiochemical Centre, Amersham, Bucks. Standardization of each batch was by reverse isotope dilution against the cyanocobalamin standard (Lau et al., 1965).

7 VITAMIN B $_{12}$ (CYANOCOBALAMIN) STANDARD 1,000 pg. $/ \mathrm{ml}$. was prepared from $100 \mu \mathrm{g}$. $/ \mathrm{ml}$., Cobalin (Paines and Byrne) brand of cyanocobalamin B.P.

8 SOURCE OF SERA Seventy-five sera were assayed. Some sera were subsequently re-assayed to determine the reproducibility of the methods. Altogether 106 assays by isotope dilution and 103 by the microbiological method were carried out. Twelve sera were obtained from patients with untreated pernicious anaemia. The remainder were obtained from patients with a variety of other diseases and from normal subjects. The sera were stored for up to two months at $-20^{\circ} \mathrm{C}$. before assay.

\section{RESULTS}

The results of the assays on 75 different sera are

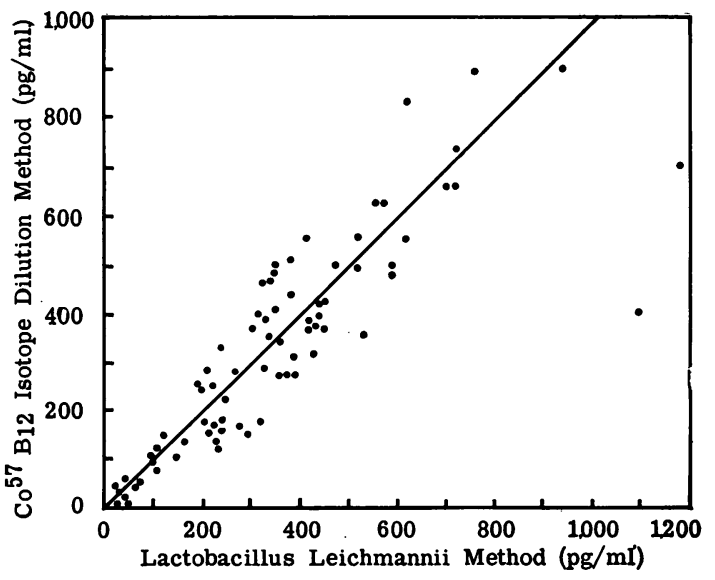

FIG. 1. Comparison of individual serum vitamin $B_{12}$ results (75 sera) obtained by radioisotope dilution and microbiological (L. leichmannii) methods. 


\section{TABLE I}

SUMMARY AND COMPARISON OF SERUM VITAMIN $B_{12}$ RESULTS OBTAINED BY RADIOISOTOPE DILUTION AND MICROBIOLOGICAL (L. leichmannii) METHODS

\begin{tabular}{lcc}
$\begin{array}{l}\text { Serum } B_{18} \text { Level } \\
\text { pg./ml. })\end{array}$ & \multicolumn{1}{|c}{ Number of Sera } & \\
\cline { 2 - 3 } & $C^{57} B_{12}$ Method & L. leichmannii Method \\
\hline$<150$ & 13 & 12 \\
$150-200$ & 11 & 6 \\
$>200$ & 51 & 57 \\
Total number of sera & 75 & 75
\end{tabular}

shown in Fig. 1 and Table I. Comparison of the values obtained by the radioisotope and microbiological methods yielded a correlation coefficient of 0.89 . It will be seen that over the range of vitamin $B_{12}$ concentration examined there was a satisfactory agreement between the two methods but that the isotope dilution method tended to give lower values when the vitamin $B_{12}$ concentration was less than $200 \mathrm{pg} . / \mathrm{ml}$.

The reproducibility of each method was assessed by replicate assays on one serum (sample d) set up in a single batch, and also by repeated assays over a period of five months on each of three different sera (sample $\mathrm{a}, \mathrm{b}$, and c). These results are shown in Table II from which it can be seen that for practical purposes the reproducibility of the assays by the radioisotope method was satisfactory, and that in this respect it compared favourably with the microbiological method. To obtain this degree of reproducibility with the radioisotope method it was found necessary to use larger volumes of serum and reagents than those recommended by Lau et al. (1965).

\section{DISCUSSION}

The results of this study substantiate the claim of Lau et al. (1965) that their radioisotope method can be used to determine the amount of vitamin $B_{12}$ in serum and that the values correlate reasonably well with those obtained by microbiological assay. Our study differs from that of Lau et al. (1965) in that we have used Lactobacillus leichmannii and they have used Euglena gracilis as the test organism for the microbiological assay. The radioisotope method would therefore seem to correlate favourably with either of the standard microbiological methods. Like Lau et al. (1965) we have found that the radioisotope method tends to give lower values than the microbiological method on sera containing reduced amounts of vitamin $B_{12}$. This might mean that vitamin $B_{12}$-deficient sera can be identified with greater certainty by the radioisotope method but many more sera would have to be assayed to know whether this is a consistent trend. What appears certain is that the radioisotope method is at least as reliable as the microbiological method in picking out $B_{12}$-deficient sera.

In order to obtain better reproducibility of results with the radioisotope method we have used larger volumes of serum and reagents than those used by Lau et al. (1965). It was found that larger volumes could be dispensed more easily and accurately and

TABLE II

REPRODUCIBILITY OF SERUM VITAMIN B 12 RESULTS OBTAINED BY THE RADIOISOTOPE DILUTION METHOD AND BY MICROBIOLOGICAL ASSAY

\begin{tabular}{|c|c|c|c|c|c|c|c|c|}
\hline \multirow{3}{*}{$\begin{array}{l}\text { Method } \\
\text { Isotope dilution }\end{array}$} & \multirow{3}{*}{$\begin{array}{l}\text { Times of Assay } \\
\text { Over a period of } 5 \text { months }\end{array}$} & \multirow{3}{*}{$\begin{array}{l}\text { Serum } \\
\text { a }\end{array}$} & \multirow{3}{*}{$\begin{array}{l}\begin{array}{l}\text { Number of } \\
\text { Replicate Assays }\end{array} \\
4\end{array}$} & \multicolumn{5}{|c|}{ Serum Vitamin $B_{12}$ Concentration (pg. $/ \mathrm{ml}$.) } \\
\hline & & & & \multicolumn{4}{|c|}{ Individual Values } & \multirow{2}{*}{$\frac{\text { Mean }}{35}$} \\
\hline & & & & 10 & $\mathbf{0}$ & 50 & 80 & \\
\hline & & $\mathbf{b}$ & 6 & $\begin{array}{l}280 \\
400\end{array}$ & $\begin{array}{l}350 \\
520\end{array}$ & 370 & 360 & 380 \\
\hline & & c & 7 & $\begin{array}{r}1,080 \\
760\end{array}$ & $\begin{array}{l}850 \\
760\end{array}$ & $\begin{array}{l}890 \\
890\end{array}$ & 990 & 890 \\
\hline & In a single batch & d & 9 & $\begin{array}{l}510 \\
530 \\
500\end{array}$ & $\begin{array}{l}500 \\
530\end{array}$ & $\begin{array}{l}520 \\
530\end{array}$ & $\begin{array}{l}540 \\
550\end{array}$ & 525 \\
\hline \multirow[t]{4}{*}{ L. leichmannii } & Over a period of 5 months & $\mathbf{a}$ & 5 & $\begin{array}{l}30 \\
40\end{array}$ & 60 & 10 & $<25$ & 30 \\
\hline & & $\mathbf{b}$ & 13 & $\begin{array}{l}400 \\
450 \\
390 \\
435\end{array}$ & $\begin{array}{l}500 \\
480 \\
430\end{array}$ & $\begin{array}{l}420 \\
450 \\
410\end{array}$ & $\begin{array}{l}440 \\
410 \\
425\end{array}$ & 430 \\
\hline & & c & 3 & 860 & 660 & 750 & & 760 \\
\hline & In a single batch & d & 4 & 480 & 480 & 480 & 420 & 465 \\
\hline
\end{tabular}


that this modification greatly improved the reproducibility and accuracy of the method in our hands.

Although results can be obtained in a matter of hours with the radioisotope method compared with at least three days for microbiological methods, there is seldom a pressing need to know the serum $B_{12}$ level quickly. The main advantage of the relative rapidity of the assay is the saving of technicians' time: a batch of sera assayed radioisotopically takes less time than the same number assayed microbiologically. A potential advantage of the radioisotope method is that it appears to lend itself more easily to automation which might allow large-scale assays to be carried out, perhaps in regional centres.

In terms of material the radioisotope method costs about six times as much as the microbiological method, i.e., about $2 \mathrm{~s}$. as opposed to $4 \mathrm{~d}$. per serum sample. The greater expense is largely due to the cost of the ${ }^{57} \mathrm{CoB}_{12}$. Furthermore, the isotope method requires relatively specialized counting equipment and unless an automatic counter is incorporated (which increases the cost of the equipment) the counting of large numbers of samples can be tedious and time consuming. Microbiological methods can be set up in almost any laboratory since the materials are easily available and no specialized equipment is necessary. No particular safety precautions are required for the microbiological procedures whereas there is the potential hazard of working with radioactive materials in the isotope methods.

Almost all laboratories carrying out vitamin $B_{12}$ assays use one or other of the standard microbiological methods. Once established these methods work satisfactorily and it remains to be seen whether a familiar and reliable microbiological method will be readily abandoned for the radioisotope procedure.

We are grateful to Dr. I. Chanarin for helping us to set up the microbiological assay and for supplying some sera, and to Dr. S. Ardeman for instruction in the method of intrinsic factor assay.

\section{ADDENDUM}

Since this paper was accepted for publication, it has been found that occasionally and unpredictably in some assay batches, the net counts per 100 seconds of the intrinsic factor control have been a little lower than expected and so the serum $B_{12}$ values for the sera assayed in that batch have also been lower than expected. This may be due to the fact that while there are serum proteins in the serum tubes which may protect the intrinsic factor against damage by acid, there are none in the intrinsic factor control tubes.

Now in every batch, a serum sample known to contain $<25 \mu \mu \mathrm{g}$. $/ \mathrm{ml}$. of vitamin $\mathrm{B}_{12}$ is assayed, and if the net counts per 100 seconds of the serum are higher than the net counts per 100 seconds of intrinsic factor control, the serum value is the one used for the value IF in the equation for the calculation of serum $B_{12}$ concentration.

\section{REFERENCES}

Barakat, R. M., and Ekins, R. P. (1961). Lancet, 2, 25

Gottlieb, C., Lau, K. S., Wasserman, L. R., and Herbert, V. (1965). Blood, 25, 875.

Lau, K. S., Gottlieb, C., Wasserman, L. R., and Herbert, V. (1965). Ibid., 26, 202.

Rosenthal, H. L., and Sarett, H. P. (1952). J. biol. Chem., 199, 433. Rothenberg, S. P. (1961). Proc. Soc. exp. Biol. (N. Y.), 108, 45. 